\title{
PROSPECTS FOR THE DEVELOPMENT OF MARKETING
}

\author{
Musayeva Shoira Azimovna \\ Associate Professor, Candidate of Economic Sciences, Samarkand Institute of Economic and \\ Services
}

\author{
Usmonova Dilfuza Ilkhomovna \\ PhD , Associate Professor, Samarkand Institute of Economics and Service
}

\author{
Usmanov Farzod Shokhrukhovich \\ Student, Samarkand Institute of Economics and Service
}

Article DOI: $\underline{\text { https://doi.org/10.36713/epra5261 }}$

\begin{abstract}
Article describes innovative technologies and marketing arrangements; perspectives of managing marketing activities; disclosed content tools, allowing customers to expand the scope and strategies to maximize the relevance of marketing approaches based on scientific research activity; research of personal inquiries of consumers is analyzed.
\end{abstract}

KEY WORDS. Marketing, marketing research, innovation, development.

\section{INTRODUCTION}

Market development entails the most significant plans and strategies that ensure all marketing processes are productive. An institution in California had a controversy of marketing that took five years to be productive. It contained several concepts and marketing strategies which were incorporated to produce a developed market. However, development of marketing is known to be incorporation of various concepts that are executed, have proper pricing, promotion and ways of distribution made affordable to satisfy organizational and individual objectives ((Burns et al., 2014). Therefore, the paper will seek to address marketing concept in relation to its initiatives, strategies, processes and trends. Market development contained several early stages that if followed systematically leads to the initial status of a business or an organization. Based on this, some activities have to be aligned with the business, and they must have impacts to the developing market. It takes into action the early stages which are setting of business goals, mission and also have objectives that the business or an organization must attain.

The entire business is facilitated in the provision of goods and services, as well as recommendations for the better services offered. Development of a market and the processes in marketing are planned and enacted by the executives of an organization. All the prospective measures that ought to be taken in attaining either long-term or shortterm goals are implemented (McDonald \& Wilson). When all the goals have been met, development of an organization takes place. Achieving of all set goals becomes of benefit to both the organization and business executives as well. For the growth of a market, some strategies have to be adhered to attain the set goals. Attaining a marketing process there is the need for planning, developing and also implementation to make it the recommended marketplace. Notably, this is done by following up of the mission stated, 
objectives and goals that have been set. In having the named concepts, a business meets all the market requirements and becomes the most competitive (Scarborough). In this case, customers are provided with the confidence in acquiring their services from the organization. The existing marketing strategies have three phases that help in business development, stimulating customers flow and to remain competitive in market environment. The three steps are; planning phase, implementation phase and evaluation or the control phase. The planning phase is the most significant phase as helps in analyzing the internal strengths and weaknesses, technological changes, industrial and cultural shifts as well as an external competition. Based on this, planning phase analysis help in provision of an overview of what the business needs and what it oughts' to eliminate. However, the strategies used in marketing has other four components that help in the provision of a pictorial view of the company or an organization. The considered marketing elements involve the SWOT analysis, marketing program, the setting of the market and program goals and finally the market-product focus and the goal setting. SWOT analysis helps in the definition of strengths, weaknesses, opportunities and threats that are revealed in an organization (Scarborough). Identification of the SWOT analysis gives a business the necessary steps for development. The analyzing of competitors, the current and prospective customers is made effective, as well as assessing the company by identifying the followed marketing trends (Scarborough, 2016). Completion of the SWOT analysis should be made useful for the marketing plan development and also ensure that all measures set are attainable.

As a result, organizations are able proper plan in product marketing. A marketing plan helps in the identification of the required and the most determined decisions on products that are enquired by customers. According to Mintu \& Winston, identifying the most recommended products allows customers to be acquiring goods and services from the particular organization. Most importantly, clients are assured that the company or organization is efficient and reliable in the provision of anything that is needed. However, all customers make it a routine in buying of the products from the organization and helps in the development of a market (Mintu \& Winston). The development comes in due to stiff competition that is created in the marketing environment. Adhering to the marketing plan helps both company and executives in meeting all the set objectives, and also the market develops. The setting of marketing and product goals increases the chances market development if all customer needs are met, and any complaints and suggestions provided are well understood. The business is able to point out of differences that make a market unique. Identification of the unique qualities helps a market in meeting most of the set goals and objectives since there will be stiff competition in the marketplace (Gummerus). In addition, the setting of market product goals selects the target market in which all the products and services would be taken. As a result, effective market development is enhanced since the targets act as a guide in what would be done and how it shall be done. Market-product focus and the goal setting gives the affirmation to the company on what it should provide to the market. Among the components used are price strategy, place strategy, promotion strategy and the product strategy. Pricing strategy helps in making a price listing that will enable customers with an overview on how a certain product costs. Place strategy assist a market in identifying where the products and services should be taken (Scarborough). The marketing process is done with the aim of meeting a large number of customers. In addition, promotion strategy necessitates an organization in coming up with ideas of making direct sales which shall be done either on advertising, through public relations or sales promotion. Scarborough emphasized promotion strategy helps in spreading the good news of a business within a short period. Product strategy focuses on the features, branding, packaging and also provision of warrants. It helps in the development of business after gaining a loophole that will increase the sales rate. The second phase is the implementation that requires the action enactment. This phase depends on the actions taken during the first phase of planning. Following up of the planning phase leads to an adequate and a competent structure of a business. In this phase, sales forecast and proper budgeting impact the company positively. The phase uses four components that help in development. This element include obtaining of resources, designing the marketing organization, developing adequate planning schedules and also the execution of a marketing plan (Gummerus). Hence, all development plans that have been set for a company are made effective. Obtaining resources helps in summing up of all monetary value that would be used in the marketing of new products. In this case, the business is able to make proper financial planning that require professional executives to manage monetary values. Firms are assured to develop for there would be no wastage of money. In designing of the marketing organization, there is the placing of plans in a hierarchical order (Mintu \& Winston). Arranging of the 
marketing plans helps in starting with the most critical plans that would be effective in the business. Giving priorities to the most significant needs in an organization ensures that the flow of events leads to success. Also, it eases the planning concepts that are used by executives in carrying out various activities. Developing planning schedules helps in the allocation of tasks that ease accomplishments. According to Baker, the planning process is done by the executives of a business where they have to outline all the needs starting with why it is needed and how it shall be done. A proper schedule is formulated to contain all events arranged systematically for easy follow-up. Executing of marketing plans is the way all firm marketing plans are set to be in detail and thus lay their focus on the success of the business (Baker). Achievements are met by use of all strategies and tactics that are needful in market development. The third phase is the evaluation or the control phase. The phase focuses on checking what has been planned since the first phase shows how things were implemented with the intention of meeting all the marketing goals. However, evaluation and control phase ensure that all the results obtained have been aligned with the necessary measures set in developing an achievable market plan (McDonald \& Wilson). This phase require executives and managers to have distinctive observations and make necessary rectifications on some of the negativities that may be pointed out. The main aim of the evaluation phase is to do away with all deviations that fail to align with the set goals of the intended market. To have a positive divergence of the intended plans, some factors facilitate the evaluation and effectiveness of all marketing strategies put in place. Baker maintained that, the regarded elements include strategy versus tactic, measurable versus vague, actionable versus contingent and finally marketing strategy. Strategy versus tactic helps in the scrutinizing the strategies that have been set in the definition of goals and tactics that give actions which are to be used in meeting all the set goals (Baker). The measurable versus the vague gives the identification after the set goals have been achieved. However, it acts as a measuring plan thus it becomes easy in verification of the plan intended. The action versus contingent makes use of the strategic goals that are achievable and thus offers support to the tactics outlined. It keeps away all the strategies regarded as unproductive. The marketing strategy gets on the action with the tactics that were identified in the setting of goals and objectives. It is done to ensure nothing is left behind in the success and development of a business. All marketing concepts have to be engaged in a certain order of processes that help in achieving the intended goals and objectives. Modelling of the marketing is done through a series of sequential steps that have to be analyzed to come up with opportunities that are of significance to the business.

\section{REFERENCES}

1. Borland, H., \& Lindgreen, A. Sustainability, epistemology, ecocentric business, and marketing strategy: Ideology, reality, and vision. Journal of Business Ethics, 117(1), 173-187.

2. Burns, A. C., Bush, R. F., \& Sinha, N. Marketing research (Vol. 7). Harlow: Pearson.Christopher, M., Payne, A., \& Ballantyne, D. Relationship marketing. Routledge.Gummerus, J. Value creation processes and value outcomes in marketing theory: strangers or siblings?. Marketing Theory, 13(1), 19-46.

3. Khan, M. T. The concept of'marketing mix'and its elements (a conceptual review paper). International journal of information, business and management, $6(2)$,

4. McDonald, M., \& Wilson, H. Marketing Plans: How to prepare them, how to profit from them. John Wiley \& Sons.

5. Mintu-Wimsatt, A. T., \& Winston, W. Environmental marketing: strategies, practice, theory, and research. Routledge.

6. Scarborough, N. M. Essentials of entrepreneurship and small business management. Pearson. 